\title{
THE STUDY OF GOVERNMENTAL AGENCIES
}

The tendency toward crystalization which is inherent in our judicial law reveals itself also in the bibliography of our profession, and in the curricula of our law schools. One of the results of it is the sloth and reluctance with which the law schools are responding to the demand, constantly becoming more urgent, that less attention be devoted to the details of the older branches of the law, and more bestowed upon those subjects which are so speedily becoming equally productive of litigation. The older branches-torts, contracts, sales, property-rest upon the basic principles of the private law, the study of which is of the greatest importance; but an exhaustive drilling in their details may well be deemed of secondary importance to a thorough study of the principles which underlie those more modern branches-constitutional and statutory rights, corporate powers and franchises, instrumentalities of government, taxation and assessments, eminent domain. The fundamental theories of public municipal law especially, cannot be grasped during the investigation of particular problems in practice. The confusion caused by the opinions of judges who, in disposing of a case, are unable to take a comprehensive view of the whole section of the law, bears witness to that unfortunate truth.

With the law of private corporation, the law schools have fairly caught up. With another branch of the law, one which has advanced with almost equal rapidity-the law of governmental agencies-neither law schools nor text-writers have kept abreast. The ancient municipal corporation has been gradually disintegrated by the assignment of its functions to independent officers and boards, often accountable directly to the central government; new tribunals have been devised for the subdivisions of the state and new bodies and functionaries crowded into local administrative areas; state boards and commissions have been created in great number and with multitudinous duties; territorial electorates have entered actively into the work of administration; until the entire mechanism of public agencies has grown to enormous size and complexity. The profusion and increased activity of these agencies has induced a continual enlargement in the amount of litigation concerning them, to which the enactment 
of constitutional and statutory rules for their regulation has continually added; until the mass of law regarding them has accumulated to discouraging proportions. An examination of the index of almost any recent volume of official reports will convince one, it is believed, of the magnitude of this developement.

Until recently, almost the only attention given this subject at law schools was in a course on municipal corporatıons, at first as an offshoot of the law of corporations in general. It appeared, however, that municipal corporations could not be studied without reference to various similar bodies, such as counties and school districts, and that such bodies were themselves worthy of study; and the topic was enlarged by schools and text-writers to include all public corporations. But the law involved in the operation of local governments is not the law of corporations. It is mostly but the law of officers and official bodies-law as applicable to state officers and local boards, as applicable to those local officers and bodies which are independent as to those which are deemed agents of corporations. It is but part of a greater and independent system. That system is rapidly, by the multiplication and diversification of the instrumentalities of government, being moulded, arranged, and developed into an orderly and extensive body of law. That body was formerly treated in isolated fragments, the more prominent of which were that part of so-called constitutional law which deals with the framework of government and the separation of powers, the law of public officers, the liability of such officers for torts, the substance of what has been considered the law of extraordinary remedies, the law of public corporations, the liability of municipal corporations for torts, public easements.

No one realizes as do those who endeavor to present this portion of the law in a class-room, the present need of fitting and correlating these segregated members into a unified system. The various problems that arise in them cannot be intelligently studied separately. Examples which demonstrate this appear in every part of the subject. The limits of the power of the legislature to delegate governmental authority to municipalities must be considered with reference to the object of such bodies as defined by history and past usage, and as delineated in construing their general powers. The legislative power to delegate discretion to the electorate of a locality by referendum cannot be 
unclerstood unless it be studied together with the legislative power to delegate authority to municipalities, and the general principle of local self-government. ${ }^{1}$ In conjunction with the power of referendum and the power to delegate to municipalities, the power to confer discretionary authority on state executives and commissions should be studied. In the same connection the power of municipal councils to delegate discretion, the division between executive and legislative in municipal government, should be discussed. Other illustrations may be selected at random. The law which determines the control of a public agency over a public easement, whether the easement be acquired by dedication, by prescription, or by eminent domain, rests upon principles which are the same whether the agency be a municipal council, a county board, an independent local body, or a state commission. Even municipal ordinances do not furnish an independent topic, for in the main the same principles determine their validity as determine the validity of those of local or state boards, and those of Federal departments. The problems which arise in the procedure of city councils-notice, quorum, majority, interest and motives of members-occur also in the workings of independent and state bodies, and moreover should be considered in comparison on the one hand with the rules governing the legislature, and on the other hand with those governing town meetings and the electorate. The questions under the authority of the courts to review administrative action-those of reasonableness and the finality of administrative decision-are decided by rules which are the same whatever may be the kind of administrative agency under consideration; whether legislature, municipal council, board of tax assessors, or Federal secretary. ${ }^{2}$

If in this administrative system a corporation is inserted, the corporation as a person is itself but a public agent, and should be treated as such. The doctrine of de facto corporation, for example, is but the same as that which applies whether the subject be a government, a legislature, a court, a corporation, a board, or an officer. The accountability of a public corporation in tort for the non-performance of a political duty, or for the manner of performing a discretionary duty, is the same as that of a public officer; and the cases on the liability of such corporations

1 Opinion of Justices, I60 Mass., 586.

2 Union Bridge Co. v. United States, 204 U. S., 364; Com. v. Sisson, I89 Mass., 247. 
in tort for collateral injuries to persons or property, are bewildering to a student until they are correlated with those upon the liability of public officers for the same injuries. A recent case in Massachusetts expressly places the liability of municipal corporations and that of public officers, indeed that of all public agencies, on common principles. ${ }^{3}$

It is also noticeable that very little change in the situation of an official body is caused by incorporation; that such change as is caused is so slight that it does not furnish a distinct basis for classification. In a New York case, for example, it was held that though incorporation of a board of education relieved the members from liability for neglect of official duty, the corporate liability was determined by the same principles as had previously determined that of the members; and that the rule respondeat superior did not apply as against the corporation any more than as against the unincorporated officers. Apparently such a body is to be dealt with in most respects under the law of public officers. In a Michigan case, ${ }^{5}$ on the other hand, in which an incorporated board of fire and water commissioners was sued for negligence of an employe, the court held it to be exempt from liability for such negligence on the same ground as that on which counties and townships have sometimes been held exempt-the absence of a general taxing power. But the case involved the principle which imposes liability on a municipal corporation while acting in a commercial enterprise, or under a public service franchise; and it involved also the question whether the board was an agent of the city so that the rule respondeat superior would apply as against that body. Cases like this show that incorporated boards must also be studied together with municipal corporations. Indeed it is quite impossible to discuss the tort-liability of public officers and that of public corporations separately. The fundamental doctrine by which liability is determined is the same throughout the whole collection of official agencies.

The law of governmental agencies is a department of public law, as contrasted with private law-a department of the law that governs the State and its instruments of government, as dis tinguished from that which governs private individuals in their

3 Moynihan v. Todd., I88 Mass., 30r.

4 Wahrman v. Board of Education, 187 N. Y., 33r.

- O'Leary v. Commrs., 79 Mich., 281. 
relations toward each other. Much of the confusion that is found in the decisions has been occasioned by stupidly applying the doctrines of private law to these agencies. A total separation of the two systems would give great aid in treating and in studying them. To illustrate: the assertion which so frequently jars one's sense of exactness that a city holds its streets "in trust for the public" appears absurd, if we have in mind that the relation of trustee and cestui que trust is one of private law, and that the relation of the city to the people, in respect to its control of streets, is one of a political nature flowing wholly from statute. The absence of even a theoretical liability on a State in tort, becomes instantly obvious upon refiecting that the law of torts is private law, applicable only among individuals in their intercourse with each other. The usual immunity of public agencies from liability for the negligence of subordinates or employes seems to be without logical foundation until it is remembered that the rule respondeat superior arising from the relation of master and servant, is a rule of private law concerning a private law relation, the essentials of which are not present between superior and subordinate or between public body and employe in the official system.

Recently several eminent scholars have advocated the separate classification and connected study of public law topics-International Law, Constitutional Law, Public Officers, Public Corporations. Concurrently there has been an effort made to gather the branches that deal with public agencies into a single field. There appear to be three main departments of public law-Public International Law, which governs the State in its relation to other States; the Law of Constitutional Limitations, which limits the power of the State over the individual; the Law of Governmental Agencies, which governs the State's instrumentalities of government.

One of the worst difficulties in dealing with the latter department is that of choosing a name. The title Administrative Law has been adopted by Professor Goodnow in a book in which he outlines the subject, ${ }^{8}$ and that title has been adopted in several law schools. In the University of Wisconsin a complete course is given under that name, which includes municipal corporations. In Boston University Law School, the course has been termed "Administrative Law and Public Corporations." Pro-

"Principles of the Administrative Law of the United States. 
tests have been made against the adoption of the title "Administrative Law" to characterize this branch of the law in its entirety. The law of other than strictly administrative bodies is included. The term "administrative" is not significant in itself under the American system; and it leads to unfortunate confusion among the less initiated because of its universal association with probate law. . Would the title "Governmental Law" or "Governmental Agencies," be proper?

But it is the tenacity with which old forms are clung to, the slothfulness to follow these scholars and to comply with the evident needs of the student and the profession, that is at present remarkable in the law schools of the country. It is hoped that text-writers and law schools will soon begin to handle this portion of the law comprehensively and in an orderly way, under a new title and a new scheme of treatment. The spreading out of the books and courses on municipal corporations, and the scanty treatment of the separation of powers under the head of constitutional law, are scarcely sufficient.

John E. Macy.

' See for example Woerner's Law of Administration, Vol. II; Pritchard on Wills and Administration; Illinois Administration Act. 